\title{
INFLUENCE OF SPATIAL ORIENTATION OF FRAME BUILDINGS ON METAL CAPACITY OF STEEL COLUMNS
}

\author{
Pashynskyi V.A., Doctor of Technical Sciences, Professor, \\ pva.kntu@gmail.com, ORCID 0000-0002-5474-6399 \\ Central Ukrainian National Technical University, Kropyvnytskyi \\ 8, Prospekt Universytetskyi, Kropyvnytskyi, 25006, Ukraine
}

\begin{abstract}
The calculated values of wind pressure are identified without taking into account changes in wind speed and pressure from different directions. Current load standards in Ukraine allow taking into account the decreasing coefficients of wind direction if there is sufficient statistical justification and when the objects are located on open flat terrain. The purpose of this work is to identify possible effect of considering the orientation of frame buildings and corresponding coefficients of the wind direction when designing steel columns of one-story frame buildings.

By analyzing design and calculated parameters of one-story industrial and civil buildings, possible limits of their change were established, and a plan for the experimental design of columns from broad-flanged rolling H-beams was developed and implemented. A dependence was obtained and described by analytical expression that allow forecasting steel consumption for the columns of singleaisle one-story buildings, taking into account their height, total load from roof and active component of wind pressure.

Based on the results of earlier studies, the characteristic values of wind pressure and generalized wind direction coefficients were established for each of 25 regions of Ukraine. For most part of the territory of Ukraine, minimum wind loads are realized when wind directions are north-south or northeast-south-west. Generalized wind direction coefficients, together with the formula for the forecasting mass of columns, made it possible to identify possible savings in steel on the columns of one-story buildings taking into account spatial orientation of buildings.

On average, throughout the territory of Ukraine, metal consumption of rolling columns decreases by $4.2 \%$, and in some cases, depending on the region, wind direction and building height, it can decrease to $17.5 \%$. Significant influence of the underlying surface and surrounding buildings on the nature of the wind flow allows wind direction coefficients to be taken into account only when calculating the frames of buildings located in an open flat area, under conditions that their values are statistically substantiated using the results of wind observations at nearest meteorological stations.
\end{abstract}

Keywords: steel columns, metal capacity, orientation of buildings, wind pressure.

Introduction. The results of meteorological observations indicate that wind velocity and pressure vary depending on its direction. Characteristic values of wind pressure in the State Construction Standards (SCS) B.1.2-2:2006 "Loads and influences" are set in a safety margin as the maximum values from all directions. The possibility of designing buildings considering their orientation in the cardinal directions is provided in the load standards by including the decreasing coefficient of the wind direction $\mathrm{C}_{\mathrm{dir}}$ in the calculation. It is recommended to take this coefficient equal to one, but if there is a sufficient statistical substantiation, it is allowed considering smaller values of $\mathrm{C}_{\mathrm{dir}}$ when locating objects on the open plain. The expediency of considering orientation of buildings and adjusted wind pressure for the corresponding wind direction is determined by possible savings of steel, the value of which can be determined by the results of experimental design of columns.

Analysis of recent research and publications. Wind load on a building is determined according to the load standards $[1,2]$ taking into account geographical area of construction, the established service life of the building and a number of reliability coefficients that reflect the nature of the interaction of building with the wind flow. One of them is the coefficient of wind direction, which specifies the wind load taking into account orientation of the building. Considering this

Bulletin of Odessa State Academy of Civil Engineering and Architecture, 2021, no. 82, page 56-63 
coefficient is permissible [1] when designing buildings located on open plains, if there is sufficient statistical substantiation. In other cases, it is recommended to take it equal to one.

Studies of wind pressure in different directions were performed in works $[3,4]$. The result of these works is the wind direction coefficients $C_{\text {dir }}$ for eight rhumbs published in [4] for each of the administrative regions of Ukraine. Despite relatively uniform distributions of wind pressure by directions for meteorological stations in Ukraine, the recommended [4] $\mathrm{C}_{\mathrm{dir}}$ coefficients generally vary from 0.5 to 0.8 and average 0.64 . This indicates the possibility of a significant reduction in wind load on frame buildings, taking into account the orientation of the transverse frames in the cardinal directions.

The method of administrative and territorial zoning of climatic loads has been implemented in work [5]. The characteristic values of snow cover weight and wind pressure are given for each region, which can be used instead of the corresponding values from the territorial zoning maps [1]. The use of data in [5] allows analyzing metal content of the carcass columns for the territory of each of the regions of Ukraine, taking into account the influence of wind direction coefficients, which in [4] are also given in terms of regions.

In general, the available information allows identifying the effect of considering coefficients of wind direction in the design of frame buildings, but such studies have not been carried out previously.

The objective of the article is to identify possible effect of considering orientation of frame buildings and the corresponding wind direction coefficients in the design of steel columns of singlestorey frame buildings.

Requisites and baseline information. The task is realized by experimental design of steel columns of one-storey buildings at various combinations of constructive and design parameters influencing metal capacity of columns. For common single-storey industrial and public buildings, these parameters can take the following values:

- building height in the range from $6 \mathrm{~m}$ to $18 \mathrm{~m}$;

- building bay in the range from $12 \mathrm{~m}$ to $36 \mathrm{~m}$;

- spacing of transverse frames from $4 \mathrm{~m}$ to $12 \mathrm{~m}$;

- constant load from the weight of load-bearing and enclosing structures of roofs in the range from $200 \mathrm{~Pa}$ for a cold roof from a steel profiled flooring on purlins to $1500 \mathrm{~Pa}$ for the operated warmed roof with green plantings;

- characteristic value of snow cover weight according to SCS [1] from $800 \mathrm{~Pa}$ to $1800 \mathrm{~Pa}$;

- characteristic value of wind pressure according to SCS [1] from $400 \mathrm{~Pa}$ to $600 \mathrm{~Pa}$;

- reliability coefficients according to the maximum calculated value of snow and wind load $\gamma_{\mathrm{fm}}=1.04$ for industrial buildings with a fixed service life $\mathrm{T}_{\mathrm{ef}}=60$ years and $\gamma_{\mathrm{fm}}=1.14$ for public buildings with $\mathrm{T}_{\mathrm{ef}}=100$ years;

- importance coefficient for buildings of different classes of importance $\gamma_{\mathrm{n}}=1.00 \ldots 1.25$;

- design resistance of steel C 245, which in accordance with the requirements of SCS B.2.6198:2014 "Steel structures" [6] are often used for columns of public and industrial buildings, equal to $\mathrm{R}_{\mathrm{y}}=230 \mathrm{MPa}$ or $\mathrm{R}_{\mathrm{y}}=240 \mathrm{MPa}$ depending on the thickness of the profiled steel bars;

- coefficient of operating conditions for columns $\gamma_{c}=1,0$.

The analysis showed that in order to reduce the amount of experimental design, these parameters can be combined into three generalized factors:

$-\mathrm{H}$ is the height of the columns from the edge of the foundation to the mark of the bottom of the span piece of the transverse frame;

- $\mathrm{N}$ is vertical load from the roof, which takes into account the building bay and spacing of the transverse frames, the calculated values of constant and snow load, considering the service life of the building.

$-\mathrm{q}_{\mathrm{a}}$ is the active wind pressure, which takes into account the height of the building, spacing of the transverse frames, characteristic value of the wind pressure and service life of the building. The passive wind pressure $\mathrm{q}_{\mathrm{a}}$ on the leeward wall of the building $\mathrm{q}_{\mathrm{n}}$ and the wind load on the roof structure, located above the bottom of the span piece of the frame $F_{w}$, are approximately proportional to the value of $\mathrm{q}_{\mathrm{a}}$. 
The limits of change of generalized factors are established considering all possible combinations of the constructive and calculated parameters listed above which are considered at their identification. Based on the results of the evaluation, a plan of experimental design was developed. The plan provides selection of sections of 125 columns for all possible combinations of generalized factors. Their values are presented in Table 1.

Table 1 - Plan of experimental design of columns of single-storey buildings

\begin{tabular}{|l|c|c|c|c|c|c|}
\hline \multirow{2}{*}{\multicolumn{1}{|c|}{ Variable factors }} & Marking, & \multicolumn{5}{c|}{ Values of factors by levels } \\
\cline { 3 - 7 } & dimension & 1 & 2 & 3 & 4 & 5 \\
\hline Column height & $\mathrm{H}, \mathrm{m}$ & 6 & 9 & 12 & 15 & 18 \\
\hline Vertical load on the column & $\mathrm{N}, \mathrm{kN}$ & 30 & 120 & 210 & 300 & 390 \\
\hline \multirow{3}{*}{ Wind pressure on the frame } & $\mathrm{q}_{\mathrm{a}}, \mathrm{kN} / \mathrm{m}$ & 0.60 & 1.55 & 2.50 & 3.45 & 4.40 \\
\cline { 2 - 7 } & $\mathrm{q}_{\mathrm{\Pi}}, \mathrm{kN} / \mathrm{m}$ & 0.45 & 1.16 & 1.88 & 2.59 & 3.30 \\
\cline { 2 - 7 } & $\mathrm{F}_{\mathrm{w}}, \mathrm{kN}$ & 4.0 & 12.0 & 20.0 & 28.0 & 36.0 \\
\hline
\end{tabular}

The selected values of the three generalized factors almost completely cover possible limits of change in the structural and design parameters of single-storey buildings. Five values of each of the factors with a constant step of change will allow identifying and analyzing in detail the dependences of mass and other parameters of the designed columns on the height of the building, the load on roof and the wind.

Experimental design of the columns. Steel columns of frameworks of one-storey one-span buildings without overhead traveling cranes are designed. The columns are rigidly fixed in the foundations, and the span pieces are hinged with the transfer of vertical load along the axis of the column. Based on the accepted calculation scheme of the transverse frame, the longitudinal force in the column is equal to the load from the roof $\mathrm{N}$, and the flection moment at the level of the foundation is determined by the formula that takes into account wind pressure and column height.

All columns are designed from broad-flange rolled beam with parallel flanges in accordance with the requirements of the norms [6] for strength in eccentric compression, stability in the plane and from the plane of the frame, as well as ultimate flexibility. According to [6], the calculated length of the columns in the plane of the free frame is equal to $l_{x}=2 \cdot H$. The calculated length from the plane of the frame when attached to the foundation and at the level of the span piece is equal to $l_{y}=H$, and in the presence of an intermediate braces girder on the columns $l_{y}=0,5 \cdot H$. Without such a girder it was possible to design only 26 columns with the height of $6 \mathrm{~m}$ and $9 \mathrm{~m}$. The generalized results of calculations of 125 columns are given in Table 2.

Table 2 - Generalized results of selection of sections of columns

\begin{tabular}{|l|c|c|c|}
\hline \multicolumn{1}{|c|}{ Design parameters } & Minimum & Maximum & Average \\
\hline Load from roof coating N, $\mathrm{kN}$ & 30 & 390 & 210 \\
\hline Flection moment in the column $\mathrm{M}, \mathrm{kN} \times \mathrm{m}$ & 21.8 & 970.0 & 303.5 \\
\hline Sections of H-beams & 20-broad flange-1 & 70 -broad flange- & \\
\hline Cross-sectional area of the column A, cm & 39.0 & 261.8 & 136.7 \\
\hline Utilization ratio relative to the axis X & 0.103 & 0.987 & 0.599 \\
\hline Utilization ratio relative to the axis Y & 0.090 & 0.733 & 0.449 \\
\hline Strength utilization factor & 0.147 & 0.970 & 0.605 \\
\hline The highest utilization factor & 0.147 & 0.987 & 0.705 \\
\hline Mass of column, kg & 265 & 4133 & 1647 \\
\hline Flexibility relative to the axis X & 83 & 148 & 127 \\
\hline Flexibility relative to the axis Y & 71 & 150 & 107 \\
\hline The ratio of flexibility along the axis X & 0.638 & 1.023 & 0.907 \\
\hline The ratio of flexibility along the axis Y & 0.473 & 1.010 & 0.727 \\
\hline
\end{tabular}


The table shows that when designing the columns, H-beams from 20-broad flange-1 to 70-broad flange-2, cross-sectional areas which differ almost 7 times were used. Noteworthy are the low utilization factors of strength and stability, which indicate excess reserves of bearing capacity, an average of $40 \ldots 55 \%$. Together with the large values of flexibility, this indicates that a significant part of the cross sections of the columns was selected from the conditions of ultimate flexibility according to [6]. This situation is due to the insufficient efficiency of the cross sections of rolled H-beams, which have too large areas to provide the required radius of inertia. Thinner welded columns could be the best solution.

According to the results of experimental design, the tabular dependence of the mass of columns on the three selected generalized factors was obtained. The decisive factor is the height of the column $\mathrm{H}$. The values of the vertical load from the roof $\mathrm{N}$ and the active wind pressure $\mathrm{q}_{\mathrm{a}}$ have much smaller effect on the mass of the columns. The obtained dependence is described in analytical expression:

$$
G=8,06 \cdot H^{2}-0,365 \cdot N-16,6 \cdot q_{a}+0,097 \cdot H \cdot N+9,58 \cdot H \cdot q_{a}-85,7 .
$$

The numerical coefficients are determined with the method of least squares. The values of $\mathrm{H}$ in meters, $\mathrm{N}$ in $\mathrm{kN}$ and $\mathrm{q}_{\mathrm{a}}$ in $\mathrm{kN} / \mathrm{m}$ should be substituted for formula (1). The resulting value of the column mass is expressed in kilograms. In $90 \%$ of cases, the deviation of the mass of the columns, determined by formula (1), from the actual results of experimental design does not exceed $\pm 10 \%$. This allows using formula (1) for approximate estimate of the cost of steel for columns of singlestorey buildings with broad flange rolled H-beams.

Correction of the influence of buildings orientation. Formula (1) and the wind direction coefficients given in [4] for all regions of Ukraine allowed estimating the influence of the orientation of buildings on the metal capacity of steel columns. Taking into account the symmetry of single-aisle buildings, from the wind direction coefficients given in [4] for eight rhumbs, larger values are selected from two opposite wind directions, for example, north - south or northeast - southwest. Examples of initial and converted wind load distribution diagrams are shown in Figure 1. The inner lines of the diagrams show the data [4] for eight wind directions, and the outer diagrams show the transformed diagrams. The figure shows that for Kirovohrad region with a relatively uniform distribution of wind pressure by wind directions, the minimum value of the direction coefficient increased from $\mathrm{C}_{\mathrm{dir}}=0.64$ to $\mathrm{C}_{\mathrm{dir}}=0.76$. For Ternopil region with a more expressive non-uniformity of wind pressure in the directions, the minimum value of $C_{\mathrm{dir}}=0.36$ increased to $C_{\mathrm{dir}}=0.56$.
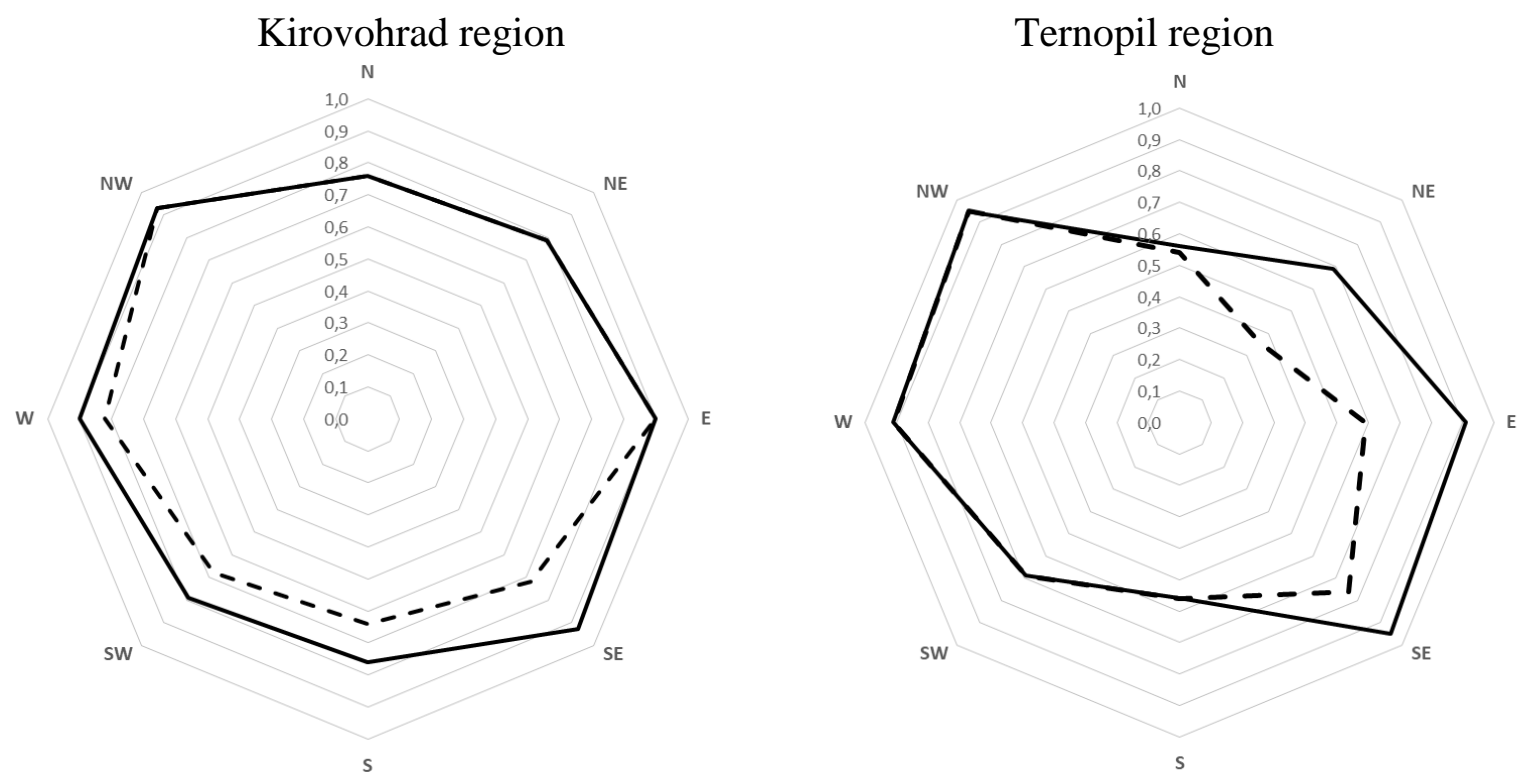

Fig. 1. Coefficients of wind direction in Kirovohrad and Ternopil regions 
The smallest direction coefficients and the corresponding orientations of the transverse frames of buildings are shown in Figure 2. The map shows that for the vast majority of Ukraine minimum $\mathrm{C}_{\text {dir }}$ coefficients are realized in wind directions north - south or northeast - southwest. It is with this orientation of the transverse frames of buildings the maximum effect from the direction of the wind when designing columns of the frame will be obtained.

Possible steel savings taking into account the orientation of buildings and wind pressure for the corresponding direction is estimated for buildings with a span of $24 \mathrm{~m}$ and height of 6,12 and $18 \mathrm{~m}$ at constant load from the weight of insulated roof based on polystyrene, which is often used in industrial and public buildings, $\mathrm{Q}_{0}=800 \mathrm{~Pa}$. The following analysis procedure has been implemented for each of the 25 regions of Ukraine:

1. According to the results of administrative-territorial zoning presented in article [5], the characteristic values of snow cover weight and wind pressure on the territory of each region are determined.

2. According to the selected value of the roof weight and the value of snow load obtained for the region, the vertical load on the column $\mathrm{N}$ is calculated.

3. Taking into account the characteristic value of wind load and building height established for the territory of the region, the values of active wind pressure $\mathrm{q}_{\mathrm{a}}$ are calculated in five variants: without taking into account the orientation of the building at $C_{\mathrm{dir}}=1$ and for four $\mathrm{C}_{\mathrm{dir}}$ values corresponding to four wind directions (Table 3).

4. For each of the three heights of buildings according to formula (1), the mass of the column is calculated at the obtained value of the vertical load and at five values of the coefficients of wind direction.

5. For each of the calculation options, the percentage of steel savings per column is determined taking into account the orientation of the building compared to the calculation at $\mathrm{C}_{\mathrm{dir}}=1$.

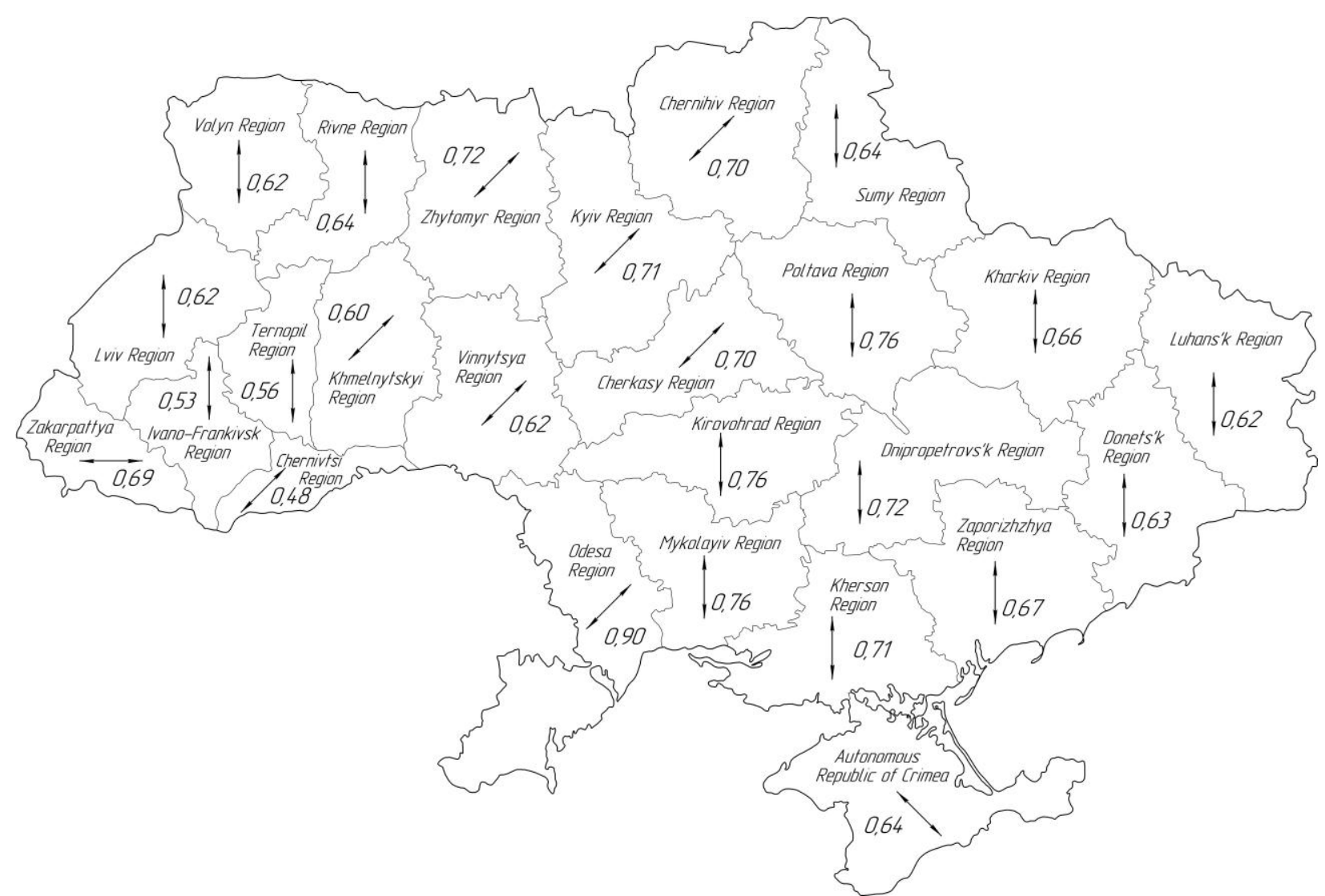

Fig. 2. Distribution of minimum $\mathrm{C}_{\mathrm{dir}}$ coefficients by directions on the territory of Ukraine

As a result of the performed calculations, steel costs for 375 columns and 300 values of possible steel savings were obtained ( 25 areas, 3 building heights, 4 wind directions and calculation 
without taking into account the direction). From the obtained results (Table 3) the smallest, largest and average percentages of savings on the territory of Ukraine at four possible orientations of cross frames of one-storey buildings are chosen.

The data in the table indicate that taking into account the orientation of a building provides reduction in the metal content of the columns by an average of $1.0 \ldots 10.4 \%$, and in some cases savings of steel can reach $17.5 \%$. The greatest savings are realized in the orientation of the transverse frames of buildings in the directions north - south and northeast - southwest, because the winds of these directions are mostly weaker than others. This is confirmed by Figure 2, which shows the predominant directions of the weakest winds. In some cases, there is a lack of steel savings due to the fact that the wind direction coefficients are approaching one.

Table 3 - Percentage of steel savings on columns of single-storey buildings

\begin{tabular}{|c|c|c|c|c|c|}
\hline $\begin{array}{c}\text { Building } \\
\text { height }\end{array}$ & $\begin{array}{c}\text { North - } \\
\text { South }\end{array}$ & $\begin{array}{c}\text { North-east - } \\
\text { South-west }\end{array}$ & $\begin{array}{c}\text { East - } \\
\text { West }\end{array}$ & $\begin{array}{c}\text { South-east - } \\
\text { North-west }\end{array}$ & $\begin{array}{c}\text { Averages by } \\
\text { directions }\end{array}$ \\
\hline \multicolumn{6}{|c|}{ The lowest percentage of savings in Ukraine } \\
\hline 6 & 1.57 & 2.49 & 0.00 & 0.50 & 1.14 \\
\hline 12 & 0.90 & 1.38 & 0.00 & 0.28 & 0.64 \\
\hline 18 & 0.66 & 1.01 & 0.00 & 0.20 & 0.47 \\
\hline \multicolumn{7}{|c|}{ The highest percentage of savings in Ukraine } \\
\hline 6 & 17.49 & 15.82 & 7.70 & 13.54 & 13.64 \\
\hline 12 & 10.54 & 8.99 & 4.29 & 8.03 & 7.96 \\
\hline 18 & 7.91 & 6.59 & 3.13 & 5.96 & 5.90 \\
\hline \multicolumn{7}{|c|}{ Average savings on the territory of Ukraine } \\
\hline 6 & 10.44 & 7.55 & 2.30 & 4.61 & 6.22 \\
\hline 12 & 6.10 & 4.39 & 1.33 & 2.72 & 3.63 \\
\hline 18 & 4.52 & 3.25 & 0.98 & 2.02 & 2.69 \\
\hline
\end{tabular}

Table 3 also shows that the percentage of steel savings decreases with increasing height of the building. At first glance, this contradicts logical notion that the effect of wind on taller buildings should be greater. A detailed analysis of the results of experimental design showed that the detected dependence is due to the selection of sections of high columns from the condition of maximum flexibility with incomplete use of their bearing capacity. The use of more efficient thin-walled welded columns will increase the effect of considering spatial orientation of buildings.

\section{Conclusions based on the research findings:}

1. According to the results of experimental design, the dependence is obtained and described by analytical expression which forecasts the cost of steel on rolled columns of single-span one-storey buildings taking into account their height, total roof load and active wind pressure component.

2. As a result of considering wind direction coefficients, metal consumption of rolled columns of single-storey buildings on average in Ukraine decreases by $4.2 \%$, and in some cases depending on the region, wind direction and building height may decrease to $17.5 \%$. On the territory of most regions of Ukraine, maximum steel savings can be obtained with the orientations of the transverse frames north - south and northeast - southwest.

3. Significant influence of the underlying surface and surrounding buildings on the nature of the wind flow makes a very prudent approach to consider the coefficients of wind direction. They can be taken into account only for buildings located on open plains, subject to statistical substantiation using the results of wind observations at nearby meteorological stations.

4. The developed method of forecasting the metal content of columns and assessing the effect of considering the coefficients of wind direction can be adapted to frame buildings of other types, including high-rise buildings, welded or trussed steel columns, and reinforced concrete columns. 


\title{
References
}

[1] DBN V.1.2-2:2006. Systema zabezpechennia nadiinosti ta bezpeky budivelnykh obiektiv. Navantazhennia i vplyvy. Normy proektuvannia. K.: Minbud Ukrainy, 2007.

[2] ENV 1991-1-4. Eurocode 1: Actions on structures - Part 1-4: General actions - Wind actions. CEN, 2002.

[3] T.M. Derkach, "Urakhuvannia napriamku vitru pry normuvanni vitrovoho navantazhennia dlia terytorii Ukrainy", Kommunalnoe khoziaistvo horodov: respublykanskyi mezhvedomstvennыi nauchno-tekhnycheskyi sbornyk. vol. 33, pp. 105$111,2001$.

[4] V.A. Pashynskyi, T.M. Derkach, "Do normuvannia vitrovoho navantazhennia dlia terytorii Ukrainy", Visnyk DDABiA, no. 2002-4 (29), pp. 107-111, 2002.

[5] V.A. Pashynskyi, H.B. Filimonikhin, M.V. Pashynskyi, "Raionuvannia kharakterystychnykh znachen klimatychnykh navantazhen na terytorii Ukrainy", Zbirnyk naukovykh prats Ukrainskoho instytutu stalevykh konstruktsii imeni V.M. Shymanovskoho, vol. 19, pp. 88-100, 2018.

[6] DBN V.2.6-198:2014. Stalevi konstruktsii. Normy proektuvannia. K.: Minrehion Ukrainy, 2014.

\section{ВПЛИВ ПРОСТОРОВОЇ ОРІЕНТАЦІЇ КАРКАСНИХ БУДІВЕЛЬ НА МЕТАЛОЕМНІСТЬ СТАЛЕВИХ КОЛОН}

\author{
Пашинський В.А., д.Т.н., професор, \\ pva.kntu@gmail.com, ORCID 0000-0002-5474-6399 \\ Центральноукраӥнський національний технічний університет, м. Кропивницький \\ пр-кт Університетський, 8, м. Кропивницький, 25006, Україна
}

\begin{abstract}
Анотація. Розрахункові значення вітрового тиску зазвичай встановлюють без урахування змін швидкості та тиску вітру різних напрямків. Чинні норми навантажень України дозволяють за наявності достатнього статистичного обгрунтування та при розташуванні об'єктів на відкритій рівнинній місцевості враховувати понижуючі коефіцієнти напрямку вітру. Метою даної роботи є виявлення можливого ефекту від урахування орієнтації каркасних будівель та відповідних коефіцієнтів напрямку вітру при проектуванні сталевих колон одноповерхових каркасних будівель.

Шляхом аналізу конструктивних і розрахункових параметрів одноповерхових виробничих і цивільних будівель встановлені можливі межі їх зміни, розроблений і реалізований план експериментального проектування колон з широкополичних прокатних двотаврів. Отримана й описана аналітичним виразом залежність, яка дозволяє прогнозувати витрати сталі на колони однопролітних одноповерхових будівель з урахуванням їх висоти, сумарного навантаження від покрівлі та активної складової вітрового тиску.

За результатами раніше виконаних досліджень встановлені характеристичні значення вітрового тиску та узагальнені коефіцієнти напрямку вітру для кожного з 25 регіонів України. Для переважаючої частини території України мінімальні вітрові навантаження реалізуються при напрямках вітру північ - південь або північний схід - південний захід. Узагальнені коефіцієнти напрямку вітру разом 3 формулою для прогнозування маси колон дозволили виявити можливу економію сталі на колони одноповерхових будівель при урахуванні просторової орієнтації будівель.

В середньому по території України металоємність прокатних колон зменшується на 4,2\%, а в окремих випадках залежно від області, напрямку вітру та висоти будівлі може зменшуватися до 17,5\%. Істотний вплив підстилаючої поверхні та довколишніх будівель на характер вітрового потоку допускає урахування коефіцієнтів напрямку вітру лише при розрахунках каркасів
\end{abstract}


будівель, розміщених на відкритій рівнинній місцевості за умови статистичного обгрунтування їх значень з використанням результатів спостережень за вітром на найближчих метеостанціях.

Ключові слова: сталеві колони, металоємність, орієнтація будівель, вітровий тиск.

\title{
ВЛИЯНИЕ ПРОСТРАНСТВЕННОЙ ОРИЕНТАЦИИ КАРКАСНЫХ ЗДАНИЙ НА МЕТАЛЛОЕМКОСТЬ СТАЛЬНЫХ КОЛОНН
}

\author{
Пашинский В.А., Д.т.н., профессор, \\ pva.kntu@gmail.com, ORCID 0000-0002-5474-6399 \\ Центральноукраинский национальный технический университет, г. Кропивницкий \\ пр-кт Университетский,8, г. Кропивницкий, 25006, Украина
}

Аннотация. Расчетные значения ветрового давления обычно устанавливают без учета изменений скорости и давления ветра разных направлений. Действующие нормы нагрузок Украины позволяют при наличии достаточного статистического обоснования и при расположении объектов на открытой равнинной местности учитывать понижающие коэффициенты направления ветра. Целью данной работы является выявление возможного эффекта от учета ориентации каркасных зданий и соответствующих коэффициентов направления ветра при проектировании стальных колонн одноэтажных каркасных зданий.

Путем анализа конструктивных и расчетных параметров одноэтажных производственных и гражданских зданий установлены возможные пределы их изменения, разработан и реализован план экспериментального проектирования колонн из широкополочных прокатных двутавров. Получена и описана аналитическим выражением зависимость, которая позволяет прогнозировать расходы стали на колонны однопролетных одноэтажных зданий с учетом их высоты, суммарной нагрузки от кровли и активной составляющей ветрового давления.

По результатам ранее выполненных исследований установлены характеристические значения ветрового давления и обобщенные коэффициенты направления ветра для каждого из 25 регионов Украины. Для преобладающей части территории Украины минимальные ветровые нагрузки реализуются при направлениях ветра север-юг или северо-восток - югозапад. Обобщенные коэффициенты направления ветра вместе с формулой для прогнозирования массы колонн позволили выявить возможную экономию стали на колонны одноэтажных зданий при учете пространственной ориентации зданий.

В среднем по территории Украины металлоемкость прокатных колонн уменьшается на $4,2 \%$, а в отдельных случаях в зависимости от области, направления ветра и высоты здания может уменьшаться до $17,5 \%$. Существенное влияние подстилающей поверхности и окружающих зданий на характер ветрового потока допускает учет коэффициентов направления ветра только при расчетах каркасов зданий, расположенных на открытой равнинной местности при условии статистического обоснования их значений с использованием результатов наблюдений за ветром на ближайших метеостанциях.

Ключевые слова: стальные колонны, металлоемкость, ориентация зданий, ветровое давление.

Стаття надійшла до редакції 20.12.2020

Bulletin of Odessa State Academy of Civil Engineering and Architecture, 2021, no. 82, page 56-63 